Trikonomika

Volume 20, No. 2, December 2021, Page. 105-111

ISSN 1411-514X (print) / ISSN 2355-7737 (online)

\title{
EMPLOYEE PERFORMANCE IS AFFECTED BY HUMAN INTELLIGENCE AND MEDIATED BY COMPETITION
}

\author{
Atty Tri Juniarti ${ }^{1}$, Bayu Indra Setia ${ }^{2}$ Irwanti $^{3}$ \\ bayu_indrasetia@unpas.ac.id \\ Universitas Pasundan \\ Jl. Tamansari No.6-8, Tamansari, Kec. Bandung Wetan, Kota Bandung, Jawa Barat 40116
}

received: 6/9/21; revised: 28/10/21; approved: 20/12/21

\begin{abstract}
This research begins with the discovery of problems in employee performance. The problem in this study is the low performance of employees, which is indicated by low human intelligence and competence. This study aims to analyze how the influence of human intelligence on employee performance is mediated by competence. With a sample of 90 people, using path analysis data analysis techniques (Path Analysis), the results show that emotional intelligence has a positive and significant effect on competence by $32.95 \%$. Also, emotional intelligence has a positive and significant effect on performance mediated by competence of $15.88 \%$. Then, intellectual intelligence has a positive and significant effect on competence by $22.49 \%$, while intellectual intelligence has a positive and significant effect on performance mediated by competence by $12.77 \%$. Furthermore, spiritual intelligence has a positive and significant effect on competence by $7.31 \%$, and spiritual intelligence has a positive and significant effect on performance mediated by competence by $2.62 \%$. Then competence has a positive and significant effect on employee performance by $73.44 \%$.
\end{abstract}

Keywords: emotional intelligence; intellectual intelligence; spiritual intelligence; competence; performance

\section{INTRODUCTION}

The development of the cigarette industry in Indonesia continues to grow from year to year. In Indonesia, the cigarette industry is included in an oligopoly commodity where the cigarette market share is mostly controlled by large industries (Hermiyanto, et al., 2016; Muchfirodin, et al., 2015). The market share of the cigarette industry in Indonesia is dominated by three large companies, namely PT. HM Sampoerna, PT. Gudang Garam, and PT. Djarum. The cigarette industry has an important role in boosting economic growth in Indonesia and is one of the domestic strategic sectors that has high competitiveness. plantations in the form of tobacco and cloves (Arifin, et al., 2015; Campus, et al., 2021). Economic conditions that support the establishment of a factory become an opportunity for investors who want to invest, so that it will increase GRDP (Gross Regional Domestic Product).

PT. Sinar Grage Jaya is one of the cigarette producing partners in collaboration with PT. HM Sampoerna Tbk. It is located in Cirebon Regency, which was established in 2006 as a company in the field of hand-held cigarette production (MPS) services. The increasing demand for cigarettes can cause employee performance to fluctuate, so that additional employees are needed to minimize the risk of declining performance from employees, which will have an impact on obstructed cigarette production and not meeting targets as determined (Astuti, 2021; Sedyati, 2019).

Employee performance is important for the company to determine the company's success in the long term. (Al \& An1l, 2016; Ponsteen \& Kusters, 2015). In line with the development of the era, performance is the result of the quality and quantity of work carried out by an employee in carrying out his duties according to the responsibilities he has been given (Ebrahimi, et al., 2016; Ladley, et al., 2015). Performance is something given by employees to determine how much they contribute to the company in the form of services and the results of the products they do (Kurniawan, et al., 2021; Poetry, 2019).

When compared with five cigarette industries in Cirebon Regency, PT. Sinar Grage Jaya has the lowest production volume in 2020 (PT. Hamsina Jaya Cirebon 352,564,282 sticks, PT. Gudang Garam Kapetakan 352,542,832 sticks, PT. Sumber Cipta Multiniaga 350,442,883 sticks, PT. Surya Mustika Nusantara Cirebon $349,500,525$ trunks, and PT. Sinar Grage Jaya only 344.565,428 sticks). By looking at the data, it seems that there is a problem in the performance of the employees of PT. Sinar Grage Jaya. 
The performance of employees at PT Sinar Grage Jaya before the pandemic and after the pandemic decreased from 2019 to 2020. There were various aspects that decreased in 2020 in the work behavior category, namely the discipline aspect and the cooperation aspect. Meanwhile, the work result category in 2020 experienced a decline, namely the quantity aspect of work and the aspect of work skills. The average total performance of employees at PT Sinar Grage Jaya Cirebon is still not optimal because, according to production employees at the center, the work assigned must reach the expected demand from the center, so sometimes employees work overtime to achieve the specified target. Employees also do not have a sense of initiative to do work and lack cooperation with fellow employees. This affects employee performance. Low employee performance is a problem that must be addressed. Low performance is one thing that reflects the failure of a company in dealing with employee development that is not according to company standards. This will create a threat to the company if the performance of its employees is not immediately repaired. Companies need employees who have optimal work improvements and are able to make positive contributions to the company's development.

Competence, human intelligence, leadership, work motivation, organizational culture, compensation, and work discipline are factors that can affect the performance of a company (Manese \& Donald, 2020; Nikezić et al., 2016; Örnek \& Ayas, 2015; Winarta, 2020; Wong \& Ngai, 2021). Having the necessary competence to answer the demands of the organization is essential. A person's competence is built from a series of dimensions, which include knowledge, skills, and attitudes. The synergy between competency dimensions will make employees have adequate characteristics to achieve their best performance in carrying out the work entrusted to them. So competence plays a role in employee performance. An employee who has competence in a job will have an impact on his performance. The higher the competence possessed by an employee, the better his performance will be. The lower the competence possessed by an employee, the lower the performance. Lack of knowledge and low skills indicate that the competence of employees is still low. Therefore, competency improvement must be carried out so that every employee can work according to their duties and responsibilities (Daniela, 2015; Skorková, 2016). Employee performance at PT Sinar Grage Jaya is low due to low competence in employees. Some of the employees have only graduated from elementary school (SD) and junior high school (SMP). This makes employees feel a lack of knowledge gained, such as experience they have had as well as information that is needed. As a result, employee knowledge remains relatively low. Then, related to the expertise possessed by the employee, errors still occur in carrying out his work because the company itself did not hold training beforehand, but immediately went to work to meet requests from the center. Then the competence of employees becomes low due to the limited education obtained and the lack of development from the company.

Intelligence in general is a general ability that distinguishes the quality of one person from another. The aspect of intelligence is something that needs to be improved as part of the company's efforts to get human resources that have a high work ethic. Human intelligence is divided into five categories, namely: emotional intelligence, intellectual intelligence, spiritual intelligence, moral intelligence, and adversity intelligence. Emotional intelligence plays an important role in achieving the best performance for an employee. Selfcontrol, enthusiasm, and perseverance, as well as the ability to motivate oneself, are all examples of emotional intelligence. By having the emotional intelligence dimension, employees can work optimally and create a conducive work atmosphere that creates a sense of comfort at work, which will ultimately have an impact on improving employee performance (Cristina \& Silvia, 2015; Lázaro \& Martínez, 2017; Lee, 2015). Employees who do not have intellectual property in themselves will find it difficult to solve problems that occur within the company and do not have solutions to problems that occur. The purpose is to assess the extent to which the intellectual intelligence of an employee can affect the performance it produces.

The existence of emotional intelligence is very important, but in fact, intellectual intelligence as measured by IQ is still important in work success. Spiritual intelligence is the intelligence of the soul that exists in employees (Budrina, 2015; Satybaldina, et al., 2015). piritual intelligence is the foundation that we have in us because this intelligence is the highest intelligence of the other intelligences. It is this spiritual intelligence that has been present in every human being since birth that makes humans live a meaningful life, always listening to the voice of their conscience, never feeling wasted, and everything they live is always valuable (Ahmed, 2016; Hanefar, et al., 2015; Saad, et al., 2015).

This research was conducted to analyze the effects of emotional intelligence, intellectual intelligence, and spiritual intelligence on employee performance, mediated by competence. Many studies have been carried out by previous researchers, but this research is also intended to fill the void left by previous studies by adding the competence variable as a mediating variable or intervening variable. 


\section{METHODS}

The research method used is the descriptive and verification method, with the unit of analysis being the employees of PT. Sinar Grade Jaya in Cirebon Regency. The population in this study were employees of the production division at PT Sinar Grage Jaya, Cirebon Regency. There were as many as 796 employees, but the sample taken was 90 employees. The sampling technique used is probability sampling with simple random sampling, while the analytical tool used is path analysis.

\section{RESULTS}

Based on the results of the validity and reliability test, each questionnaire statement item from each variable, namely emotional intelligence, intellectual intelligence, spiritual intelligence, competence, and employee performance, were all declared valid and reliable. Based on the results of the descriptive analysis of the emotional intelligence variable, an average score of 3.21 indicates that emotional intelligence is in the poor category. The results of the recapitulation of the intellectual intelligence variable obtained an average score of 3.25, indicating that the emotional intelligence variable is in the poor category. The results of the recapitulation of the spiritual intelligence variable obtained an average score of 3.41, indicating that the spiritual intelligence variable was in a good category. The results of the recapitulation of the competency variable obtained an average score of 3.39, indicating that the competency variable is in the poor category. Furthermore, the results of the recapitulation of employee performance variables obtained an average score of 3.45, indicating that the employee performance variables at PT Sinar Grage Jaya Cirebon Regency were in the good category. The results of the calculations that have been carried out can be seen in Table 1.

Table 1. The Influence of Emotional Intelligence, Intellectual Intelligence, and Spiritual Intelligence on Competency-based Performance

\begin{tabular}{ccccc}
\hline Variable & Emotional Intelligence (\%) & Intellectual Intelligence (\%) & Spiritual Intelligence (\%) & Competency (\%) \\
\hline Competency & 32.95 & 22.49 & 7.31 & \\
Performance & 15.88 & 12.77 & 2.62 & 73.44 \\
\hline
\end{tabular}

Source: Data processing, 2021

Table 1 shows that emotional intelligence has a positive and significant effect on competence by $32.95 \%$. Emotional intelligence also has a positive and significant effect on performance, mediated by the competence of $15.88 \%$. Then, intellectual intelligence has a positive and significant effect on competence by $22.49 \%$, while intellectual intelligence has a positive and significant effect on performance mediated by competence by $12.77 \%$. Furthermore, spiritual intelligence has a positive and significant effect on competence by $7.31 \%$, and spiritual intelligence has a positive and significant effect on performance mediated by competence by $2.62 \%$. Then competence has a positive and significant effect on employee performance by $73.44 \%$.

Based on the results of the calculations in Table I above, the path diagram can be described as shown in Figure 1.

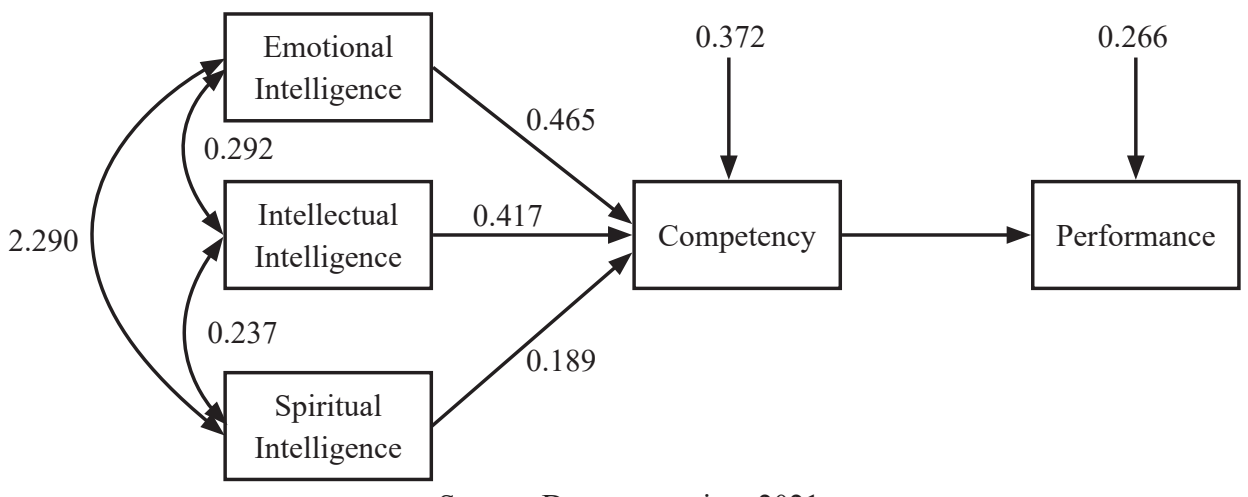

Source: Data processing, 2021

Figure 1. Overall Path Diagram

Figure 1 shows that each variable, namely emotional intelligence $\left(\mathrm{X}_{1}\right)$, intellectual intelligence $\left(\mathrm{X}_{2}\right)$, and spiritual intelligence $\left(X_{3}\right)$, has a positive and significant effect on employee performance $(Z)$ through competence $(\mathrm{Y})$ and competence $(\mathrm{Y})$ positively. and significantly affected the performance $(\mathrm{Z})$. Emotional intelligence $\left(\mathrm{X}_{1}\right)$, 
intellectual intelligence $\left(\mathrm{X}_{2}\right)$, and spiritual intelligence $\left(\mathrm{X}_{3}\right)$ affect employee performance $(\mathrm{Z})$, which is mediated by competence (Y). Thus, competence has a function as an intervening or mediating variable between emotional intelligence, intellectual intelligence, and spiritual intelligence on performance.

\section{DISCUSSIONS}

Due to failure, emotional intelligence at PT Sinar Grage Jaya is in the poor category, meaning that employees have not been able to manage their emotional intelligence in themselves, such as ways to entertain themselves, release anxiety, moodiness, or irritability, and rely on awareness and management skills. emotion. This is in line with the opinion of the quality control admin leadership, which states that employees tend not to be able to control themselves, motivate themselves, and manage emotions at work, which results in employees' emotional intelligence being low (Colomeischi, 2015; Hejazi \& Nazarpoori, 2020; Peña-Acuña \& Pisonero, 2017).

Intellectual intelligence at PT Sinar Grage Jaya is in the poor category, meaning that employees lack rational thinking and have not been able to work independently, causing knowledge of the problems at hand, making the right decisions, solving problems optimally, showing clear minds, reading with full understanding, being intellectually curious, showing curiosity, communication skills, the consequences of each decision, and showing interest in the surrounding environment is not optimal due to the limitations of education obtained. In line with the opinion of the quality control manager, employees do not dare to work individually, and the lack of communication causes employees to be less able to solve problems and make their own decisions (Budrina, 2015; Trifu, et al., 2016).

Spiritual intelligence at PT Sinar Grage Jaya is in the "good" category, meaning that employees in their work can adapt to help each other and do good as God's creatures. A person with an incomplete perception of themselves or life in general is tantamount to someone who wears glasses of the wrong size. Perception affects how he accepts everything. Therefore, wise and good things such as being autocratic, being open to other people's opinions, being pragmatic, logical thinking, forgiving, and imaginative abilities have not been properly realized for the employees themselves. In line with the opinion of the quality control admin leadership, employees are less able to think logically about a decision and are less open to the opinions of fellow employees, which makes employees feel right with their own opinions. Use spiritual intelligence as a capital to face life (Ahmed, 2016; Anwar, 2021; Hanefar, et al., 2015).

PT Sinar Grage Jaya's competence is in the poor category, meaning that employees are less motivated to develop and improve their abilities, there is no independent learning initiative and there is no training program from the company itself, which causes employee competence to be lacking in handling initiative problems in helping co-workers, friendliness and courtesy, seriousness, supported knowledge, broad knowledge, technical expertise, identifying problems and finding solutions in employees. In line with the opinion of the quality control and assurance leadership, which states that employees lack extensive knowledge, technical expertise, and the ability to identify problems in their work, this is one of the reasons for the lack of employee training (Di Berardino, 2016; Sokol, et al., 2015; Triwahyuni, et al., 2016).

Employee performance at PT Sinar Grage Jaya is in the good category, meaning that employees show quality in their work and work optimally, but are still lacking in performance, causing the employee's speed, ability, work results, and collaboration to not be shown. This is in line with the opinion of the employees of the adm quality control department, which states that employees of PT Sinar Grage Jaya have less than optimal speed, ability, and work results, one of which can be proven by the amount of production that often does not reach the target. In addition, the cooperation relationship between employees is not optimal; many employees are more concerned with their personal interests (He, et al., 2013; Lokar \& Bajzikova, 2015; Yoel, 2015).

Testing the hypothesis of the influence of emotional intelligence, intellectual intelligence, and spiritual intelligence on competence through employee performance as an intervening variable, it was concluded that there is an influence of emotional intelligence, intellectual intelligence, and spiritual intelligence on competence. The higher the emotional intelligence, intellectual intelligence, and spiritual intelligence, the higher the competence. Emotional intelligence has a greater influence than intellectual intelligence and spiritual intelligence at PT Sinar Grage Jaya. High emotional intelligence means employees can motivate themselves, manage their emotions well enough, and have maturity in solving problems (Hornuf, et al., 2021). This research is supported by research results which state that intellectual intelligence affects competence only if employees have sufficient skills. This is because their work is a repetition that continues to be repeated every day so that they are sure to be proficient and have specific skills (Kafadar, et al., 2015). Spiritual intelligence affects competence. This depends on a leader who can unite the spirituality of employees with sincere intentions at work so that employees will always work optimally (Gera, 2021). 
In contrast to research which states that the dimensions of spiritual intelligence regarding quality of life, being flexible, and having a holistic view have little effect on the high competence of employees. As a result, increased human trust in God will not necessarily result in increased competence. Therefore, spiritual intelligence has a less dominant influence on employee competence (Ahmed, 2016).

The effect of competence on employee performance means that the higher the competence, the higher the employee's performance. These results are based on research which states that if young employees have high productivity, which can make a high contribution to achieving maximum performance, and a high educational background, they are expected to be able to have good knowledge of their work (Daniela, 2015; Kristanto, et al., 2021).

\section{CONCLUSIONS}

Emotional intelligence at PT Sinar Grage Jaya Cirebon Regency is in the poor criteria, as well as intellectual intelligence at PT Sinar Grage Jaya Cirebon Regency is in the poor criteria. Meanwhile, the spiritual intelligence of PT Sinar Grage Jaya, Cirebon Regency, is in good condition. Competence at PT Sinar Grage Jaya Cirebon Regency is in poor condition, and employee performance at PT Sinar Grage Jaya Cirebon Regency is in good condition. The results of the verification test show that emotional intelligence has a positive and significant effect on competence. Emotional intelligence also has a positive and significant effect on performance mediated by competence. Then intellectual intelligence has a positive and significant effect on competence, while intellectual intelligence has a positive and significant effect on performance mediated by competence. Furthermore, spiritual intelligence has a positive and significant effect on competence, and spiritual intelligence has a positive and significant effect on performance mediated by competence. Then competence has a positive and significant effect on employee performance.

\section{REFERENCES}

Ahmed, A. 2016. Spiritual Intelligence (SQ): A Holistic Framework for Human Resource Development. In Administratie si Management Public (Vol. 2016, Issue 26, pp. 60-77).

Al, A. D., \& An11, İ. 2016. The Comparison of the Individual Performance Levels Between Full-time and Parttime Employees: The Role of Job Satisfaction. Procedia - Social and Behavioral Sciences, 235, 382-391. https://doi.org/https://doi.org/10.1016/j.sbspro.2016.11.048

Anwar, M. Z. 2021. The Effect of Islamic Spiritual Intelligence on Human Resource Performance: Individual and Organizational Perspective. In Lecture Notes in Networks and Systems (Vol. 194, pp. 1583-1594). https://doi.org/10.1007/978-3-030-69221-6_116

Arifin, M. Z., Probowati, B. D., \& Hastuti, S. 2015. Applications of Queuing Theory in the Tobacco Supply. Agriculture and Agricultural Science Procedia, 3, 255-261. https://doi.org/https://doi.org/10.1016/j.aaspro.2015.01.049

Astuti, P. A. S. 2021. Tobacco Control Stakeholder Perspectives on the Future of Tobacco Marketing Regulation in Indonesia: A Modified Delphi Study. Journal of Preventive Medicine and Public Health, 54(5), 330-339. https://doi.org/10.3961/jpmph.21.181

Budrina, E. G. 2015. Resource Factors of Intellectual Development in Younger Bilingual Students. Procedia Social and Behavioral Sciences, 185, 314-320. https://doi.org/https://doi.org/10.1016/j.sbspro.2015.03.430

Campus, B., Fafard, P., St. Pierre, J., \& Hoffman, S. J. 2021. Comparing the Regulation and Incentivization of E-cigarettes Across 97 Countries. Social Science \& Medicine, 291, 114187. https://doi.org/https://doi. org/10.1016/j.socscimed.2021.114187

Colomeischi, A. A. 2015. Predictors for Wellbeing: Emotional Factors and Expectancy for Success. Procedia - Social and Behavioral Sciences, 190, 48-53. https://doi.org/https://doi.org/10.1016/j.sbspro.2015.04.915

Cristina, O. A., \& Silvia, R. A. 2015. The Influence of Stressor Agents Over Academic Learning- Motivational Spectrum Approach. Procedia - Social and Behavioral Sciences, 180, 1406-1411. https://doi.org/https:// doi.org/10.1016/j.sbspro.2015.02.285

Daniela, P. 2015. The Relationship Between Self-Regulation, Motivation And Performance At Secondary School Students. Procedia - Social and Behavioral Sciences, 191, 2549-2553. https://doi.org/https://doi. org/10.1016/j.sbspro.2015.04.410

Di Berardino, D. 2016. Corporate Governance and Firm Performance in New Technology Ventures. Procedia Economics and Finance, 39, 412-421. https://doi.org/https://doi.org/10.1016/S2212-5671(16)30342-2

Ebrahimi, P., Moosavi, S. M., \& Chirani, E. 2016. Relationship Between Leadership Styles and Organizational Performance by Considering Innovation in Manufacturing Companies of Guilan Province. Procedia - Social and Behavioral Sciences, 230, 351-358. https://doi.org/https://doi.org/10.1016/j.sbspro.2016.09.044 
Gera, N. 2021. Human Resource Development and Spiritual Intelligence: An Investigation Amongst Management Students in Delhi NCR. International Journal of Innovation and Learning, 29(1), 45-66. https://doi. org/10.1504/IJIL.2021.111831

Hanefar, S. B., Siraj, S., \& Sa'ari, C. Z. 2015. The Application of Content Analysis toward the Development of Spiritual Intelligence Model for Human Excellence (SIMHE). Procedia - Social and Behavioral Sciences, 172, 603-610. https://doi.org/https://doi.org/10.1016/j.sbspro.2015.01.409

He, J., Mao, X., Rui, O. M., \& Zha, X. 2013. Business Groups in China. Journal of Corporate Finance, 22, 166-192. https://doi.org/https://doi.org/10.1016/j.jcorpfin.2013.05.001

Hejazi, A., \& Nazarpoori, A. 2020. Investigating the Effect of Emotional Intelligence Dimensions on Intelligent Leadership in Knowledge Age Organizations. Journal of New Approaches in Educational .... http://jedu. miau.ac.ir/mobile/article_4447.html?lang=en

Hermiyanto, B., Winarso, S., \& Kusumandaru, W. 2016. Soil Chemical Properties Index of Tobacco Plantation Land in Jember District. Agriculture and Agricultural Science Procedia, 9, 181-190. https://doi.org/https:// doi.org/10.1016/j.aaspro.2016.02.118

Hornuf, L., Schilling, T., \& Schwienbacher, A. 2021. The Relevance of Investor Rights in Crowdinvesting. Journal of Corporate Finance, 101927. https://doi.org/https://doi.org/10.1016/j.jcorpfin.2021.101927

Kafadar, H., Akınc1, Z., \& Çakır, B. 2015. Effects of the IQ up Cognitive Development Method on the Cognitive Development of 10- to 12-Year-old Children. Procedia - Social and Behavioral Sciences, 174, 3243-3253. https://doi.org/https://doi.org/10.1016/j.sbspro.2015.01.989

Kristanto, R. S., Suparwati, Y. K. 2021. Pengaruh Kompetensi SDM, Kualitas Informasi Keuangan dan Locus Of Control Terhadap Kinerja UMKM dengan Pengambilan Keputusan Sebagai Variabel .... JIEF: Journal of .... http://e-journal.iainpekalongan.ac.id/index.php/jief/article/view/3705

Kurniawan, Y. E., Sawitri, D., \& Saleh, M. 2021. Pengaruh Kualitas SDM, Terhadap Kinerja Pegawai dengan Mediasi Budaya Organisasi pada Masa Pandemic Covid 19 Di Dinas PMD Kabupaten Probolinggo. Bisman (Bisnis Dan .... http://ejurnal.unim.ac.id/index.php/bisman/article/view/1172

Ladley, D., Wilkinson, I., \& Young, L. 2015. The Impact of Individual Versus Group Rewards on Work Group Performance and Cooperation: A Computational Social Science Approach. Journal of Business Research, 68(11), 2412-2425. https://doi.org/https://doi.org/10.1016/j.jbusres.2015.02.020

Lázaro, A. M. S., \& Martínez, A. G. 2017. Intercultural Education. A Project of Attention to Diversity from the Performing Arts. Procedia - Social and Behavioral Sciences, 237, 856-862. https://doi.org/https://doi. org/10.1016/j.sbspro.2017.02.183

Lee, J.-H. 2015. A Case Study of Music-based Program in Samsung Group's Executive Education. Procedia Social and Behavioral Sciences, 174, 3214-3223. https://doi.org/https://doi.org/10.1016/j.sbspro.2015.01.985

Lokar, A., \& Bajzikova, L. 2015. International Competition and Fiscal Differentiations under Democratic Conditions. Procedia - Social and Behavioral Sciences, 210, 213-222. https://doi.org/https://doi.org/10.1016/j. sbspro.2015.11.361

Manese, L. E., \& Donald, B. W. Mac. 2020. Pengaruh Budaya Organisasi, Kualitas SDM, Disiplin Terhadap Motivasi dan Kinerja Karyawan pada PT. PLN (PERSERO) Area Manado. Jurnal EMBA: Jurnal Riset .... https://ejournal.unsrat.ac.id/index.php/emba/article/view/30086

Muchfirodin, M., Guritno, A. D., \& Yuliando, H. 2015. Supply Chain Risk Management on Tobacco Commodity in Temanggung, Central Java (Case Study at Farmers and Middlemen Level). Agriculture and Agricultural Science Procedia, 3, 235-240. https://doi.org/https://doi.org/10.1016/j.aaspro.2015.01.046

Nikezić, S., Dželetović, M., \& Vučinić, D. 2016. Chester Barnard: Organisational-Management Code for the 21st Century. Procedia - Social and Behavioral Sciences, 221, 126-134. https://doi.org/https://doi.org/10.1016/j. sbspro.2016.05.098

Örnek, A. Ş., \& Ayas, S. 2015. The Relationship between Intellectual Capital, Innovative Work Behavior and Business Performance Reflection. Procedia - Social and Behavioral Sciences, 195, 1387-1395. https://doi. org/https://doi.org/10.1016/j.sbspro.2015.06.433

Peña-Acuña, B., \& Pisonero, C. G. 2017. Ethnography and Emotions: Cultural Intelligence Applied to Motherhood Migration Process. Procedia - Social and Behavioral Sciences, 237, 446-451. https://doi.org/https://doi. org/10.1016/j.sbspro.2017.02.088

Poetry, N. R. 2019. Pengaruh Lingkungan Kerja terhadap Kualitas SDM Dampaknya pada Kinerja Karyawan PT. Permodalan Nasional Madani (PERSERO). repository.stiemahardhika.ac.id. http://repository.stiemahardhika. ac.id/648/

Ponsteen, A., \& Kusters, R. J. 2015. Classification of Human- and Automated Resource Allocation Approaches in Multi-Project Management. Procedia - Social and Behavioral Sciences, 194, 165-173. https://doi.org/ https://doi.org/10.1016/j.sbspro.2015.06.130 
Saad, M., See, T. P., Adil, M. A. M., \& Kassim, N. M. 2015. Spiritual Intelligence on Leadership Effectiveness and Food-hygiene Practices in Public Institutions. Procedia - Social and Behavioral Sciences, 201, 146-155. https://doi.org/https://doi.org/10.1016/j.sbspro.2015.08.161

Satybaldina, N., Saipova, A., Karabayeva, A., Berdibayeva, S., \& Mukasheva, A. 2015. Psychodiagnostic of Emotional States of Secondary School Teachers with Long Work Experience. Procedia - Social and Behavioral Sciences, 171, 433-437. https://doi.org/https://doi.org/10.1016/j.sbspro.2015.01.143

Sedyati, R. 2019. The Business Alteration for Tobacco Farmers: Lessons from Rural Area in Indonesia. Journal of Asian Finance, Economics and Business, 6(4), 281-286. https://doi.org/10.13106/jafeb.2019. vol6.no4.281

Skorková, Z. 2016. Competency Models in Public Sector. Procedia - Social and Behavioral Sciences, 230, 226-234. https://doi.org/https://doi.org/10.1016/j.sbspro.2016.09.029

Sokol, A., Gozdek, A., Figurska, I., \& Blaskova, M. 2015. Organizational Climate of Higher Education Institutions and its Implications for the Development of Creativity. Procedia - Social and Behavioral Sciences, 182, 279-288. https://doi.org/https://doi.org/10.1016/j.sbspro.2015.04.767

Trifu, S., Trifu, A., \& Trifu, I. 2016. Psychic Functions and Processes with Princeps Role in Learning. Procedia - Social and Behavioral Sciences, 217, 421-429. https://doi.org/https://doi.org/10.1016/j.sbspro.2016.02.003

Triwahyuni, M., Azlina, N., \& Silfi, A. 2016. ... (Sap), Kompetensi Sumber Daya Manusia (SDM) Dan Penerapan Sistem Akuntansi Keuangan Daerah Terhadap Kualitas Laporan Keuangan Skpd .... media.neliti.com. https://media.neliti.com/media/publications/122884-ID-pengaruh-penerapan-standar-akuntansi-pem.pdf

Winarta, F. P. 2020. Pengaruh Gaya Kepemimpinan, Kualitas SDM, dan Kompensasi terhadap Kinerja Karyawan PT. Kereta Api Indonesia DAOP 8 .... STIE MAHARDHIKA SURABAYA.

Wong, D. T. W., \& Ngai, E. W. T. 2021. Economic, Organizational, and Environmental Capabilities for Business Sustainability Competence: Findings from Case Studies in the Fashion Business. Journal of Business Research, 126. https://doi.org/10.1016/j.jbusres.2020.12.060

Yoel, S. 2015. Cultivating Organizational Culture within Globalized Companies Using the Wellness Kickoff Tool. Procedia - Social and Behavioral Sciences, 209, 533-539. https://doi.org/https://doi.org/10.1016/j. sbspro.2015.11.284 